ISSN 0258-7122 (Print), 2408-8293 (Online)

Bangladesh J. Agril. Res. 42(4): 673-679, December 2017

\title{
A COMPARATIVE STUDY ON CHEMICAL AND COOKING PROPERTIES OF ABIOTIC STRESS TOLERANT AND OTHER HIGH YIELDING RICE VARIETIES IN BANGLADESH
}

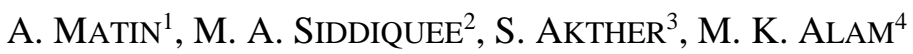 \\ AND M. S. ALI ${ }^{5}$
}

\begin{abstract}
The experiment was conducted to know the chemical and cooking properties of nineteen BRRI released high yielding rice varieties (HYVs) including salinity, drought and submergence tolerant varieties. All the rice varities were grown in normal condition. Among the HYVs, amylose content of the varieties range from 19 to $27.0 \%$ and BRRI dhan47 contained the highest amylose content $(27 \%)$. The highest amount of protein $(9.3 \%)$ was found in BRRI dhan56 followed by BRRI dhan42 (9\%) and BRRI dhan43 (8.8\%). Alkali spreading value ranged from 3.0 to 7.0. Maximum cooking time (20.5 min.) was required in the variety of BRRI dhan40. Alkali spreading value was found significantly and negatively correlated with cooking time. The kernel elongation ratio was greater than 1.1 in all the varieties except BRRI dhan62. The imbibition ratio was greater than 3.0 in all the varieties except BRRI dhan43 and BRRI dhan61. There were no significant differences between non-abiotic and abiotic stress tolerant varities in respect of chemical and cooking properties because all varities were grown in normal condition.
\end{abstract}

Keywords: Rice (Oryza sativa L.), rice varieties, amylose, kernel elongation ratio, imbibition ratio, stress tolerant.

\section{Introduction}

Rice is the staple food of about 135 million people of Bangladesh. It provides nearly $48 \%$ of rural employment, about two-third of total calorie supply and about one-half of the total protein intake. Bangladesh has a total area of $14.8 \mathrm{M}$ ha, out of which, $70 \%$ is affected by different types of flash floods. About $1 \mathrm{M}$ ha land is highly flood prone and $5 \mathrm{M}$ ha moderately flood prone. Out of $2.85 \mathrm{M}$ ha of coastal and off-shore land, about $1 \mathrm{M}$ ha is affected by varying degrees of salinity; about 5.7 M ha by drought (Anon., 2014a). Bangladesh Rice Research Institute (BRRI) has developed rice varieties tolerant to submergence, drought and salinity (Anon., 2014b). The rice millers prefer varieties with high milling and head rice out-turn, whereas consumers consider quality (Dipti et al., 2002). The amylose content of rice is considered as the main parameter of cooking and eating quality (Asghar et al., 2012). Amylose content, volume expansion, water absorption influences many of the starch properties of rice (Juliano, 1979; 1985).

\footnotetext{
${ }^{1,3-5}$ Chittagong Veterinary and Animal Sciences University, Khulshi, Chittagong-4225, Bangladesh, ${ }^{2}$ Bangladesh Rice Research Institute, Gazipur-1701, Gazipur, Bangladesh.
} 
Cooking time is important as it determines tenderness of cooked rice as well as stickiness to great extent (Asghar et al., 2012). Higher the imbibition ratio of rice, lower will be the energy content per unit volume or weight of cooked rice, as they will have more water and solid materials (Anon., 1999). The objective of the study was to find out the chemical and cooking properties of the abiotic stress tolerant varieties along with some other rice varieties.

\section{Materials and Method}

The laboratory experiment was conducted at Grain Quality and Nutrition Division of BRRI, Gazipur from October to November 2014. For this purpose 7 non-abiotic and 14 abiotic stress (Salinity tolerant-7, Submergence tolerant-2, Drought tolerant-5) tolerant rice varieties (Table 1) collected from Genetic Resources and Seed (GRS) Division of BRRI.

Table 1. Tested nineteen non-abiotic and abiotic stress tolerant rice varieties

\begin{tabular}{|l|l|l|}
\hline Non-abiotic & HYVs Varieties & $\begin{array}{l}\text { BRRI dhan58, BRRI dhan59, BRRI dhan60, } \\
\text { BRRI dhan62, BRRI dhan63, BRRI dhan64. }\end{array}$ \\
\hline Abiotic & Salinity tolerant & $\begin{array}{l}\text { BRRI dhan40, BRRI dhan41, BRRI dhan47, } \\
\text { BRRI dhan53, BRRI dhan54, BRRI dhan55, } \\
\text { BRRI dhan61. }\end{array}$ \\
\cline { 2 - 3 } & $\begin{array}{l}\text { Submergence } \\
\text { tolerant }\end{array}$ & BRRI dhan51 and BRRI dhan52. \\
\cline { 2 - 3 } & Drought tolerant & $\begin{array}{l}\text { BRRI dhan42, BRRI dhan43, BRRI dhan55, } \\
\text { BRRI dhan56, BRRI dhan57. }\end{array}$ \\
\hline
\end{tabular}

The rough (paddy) rice was dehulled by Satake rice mill. The resulting brown rice was polished for 75 second in a Satake grain-testing mill TM05. This polished rice was ground by a Cyclone sample mill. Slide Calipers was used for measurement of grain length and breadth. Milled rice was first classified into three classes based on length, very long $(>7.5 \mathrm{~mm}$ in length), long $(6.61-7.5 \mathrm{~mm}$ in length), medium (6.60-5.51 $\mathrm{mm}$ in length), and short ( $<5.50 \mathrm{~mm}$ in length). They were again classified into three classes, according to the length/breadth ratio; slender (ratio more than 3); medium (ratio 2.1-3); bold (ratio 2 or less than 2) to determine size and shape (Graham R. 2002).

For amylose content $100 \mathrm{mg}$ of rice powder was taken into a 100 milliliter volumetric flask, and then 1 milliliter of $95 \%$ ethanol and 9 milliliter of 1 molar sodium hydroxide were added. The contents were heated in a boiling water bath to gelatinize the starch. After cooling for 1 hour, distilled water was added and the contents were mixed well. For each set of samples run, nasirsail having $25 \%$ amylose standard varieties was included to serve as check. Then 1 molar acetic acid and $2 \mathrm{~mL}$ iodine solution were added with $5 \mathrm{~mL}$ starch solution of each and shaken well (Juliano, 1971). Absorbance of the solution was measured at $620 \mathrm{~nm}$ 
with a spectrophotometer such as the Jasco V-630 spectrophotometer. For the standard curve, $40 \mathrm{mg}$ of potato amylase (BDH laboratory supplies Poole, BH15 1TD) was taken. The absorbance values were plotted at $620 \mathrm{~nm}$ against the concentration of anhydrous amylose $(\mathrm{mg})$ and the conversion factor was determined (Graham, 2002).

Alkali spreading value was determined according to the procedure of Little et al. (1958). A duplicate set of six whole-milled kernels without cracks was selected and placed in a plastic box $(5 \times 5 \times 2.5 \mathrm{~cm})$. 10 milliliter of $1.7 \%$ potassium hydroxide $(\mathrm{KOH})$ solution was added. The samples were arranged to provide enough space between kernels to allow for spreading. The boxes were covered and incubated for 23 hour in a $30^{\circ} \mathrm{C}$ oven. Starchy endosperm was rated visually based on a 7-point numerical spreading scale (Graham, 2002). Protein contents were calculated from nitrogen and were determined by Micro Kjeldahl method. For elongation ratio, the length of the 20 raw and 20 cooked grains were measured to the nearest millimeter with a vernier caliper. Elongation ratio is the ratio of the cooked grain to that of raw grain (Azeez et al., 1966). Volumes of cooked and milled rice were measured by water displacement method. Five grams of milled rice was placed in a graduated cylinder containing $50 \mathrm{ml}$ of water and the change in volume was noted. Five grams of milled rice was cooked and then the cooked rice was placed in the same cylinder and the change in volume was measured. The imbibition ratio is the ratio of change in the volume of cooked to raw rice (Dipti et al., 2002). Cooking time was measured when $90 \%$ of cooked rice was totally gelatinized. All analyses were carried out in duplicate for each sample and results obtained were computed into means. The results were evaluated by Analysis of Variance and Duncan's New Multiple range Test procedures of the Statistically Analysis System (SAS, 1985).

\section{Results and Discussion}

\section{Chemical properties of nineteen rice varieties:}

Alkali spreading value ranged from 3.0 to 7.0 of the tested varieties where highest in BRRI dhan 47 and lowest in BRRI dhan43. Amylose content of the tested varieties ranged from 19 to $27.0 \%$. The highest amount of amylose (27\%) was estimated in BRRI dhan47 and the lowest (19\%) in BRRI dhan62 (Table 2). Amylose content of rice determines the hardness and stickiness of cooked rice. Amylose content higher than $25 \%$ gives non sticky soft or hard cooked rice. Rice having 20-25\% amylose gives soft and relatively sticky cooked rice (Anon., 1997). Protein content of the varieties ranged from 6.2 to $9.3 \%$ (Table 2). The highest amount protein $(9.3 \%$ ) was found in BRRI dhan56 followed by BRRI dhan42 (9\%) and BRRI dhan43 (8.8\%). On the basis of nutritional value all the varieties contained sufficient amount of protein except BRRI dhan41, BRRI dhan47, BRRI dhan51 and BRRI dhan54 which contained very little protein below the standard rate 7\% (Dipti et al., 2002). Low gelatinization temperature 
was found in terms of salinity tolerant varities where other varities showed highintermediate. The gelatinization parameters are influenced by amylopectin structure (chain length distribution), which can be varying by cultivar, location and crop year (Cameron et al., 2008).

Table 2. Chemical properties of nineteen non-abiotic abiotic stress tolerant rice varieties

\begin{tabular}{|c|c|c|c|c|}
\hline Variety/Line & $\begin{array}{c}\text { Alkali } \\
\text { Spreading } \\
\text { Value } \\
\text { (mean } \pm \text { SD ) }\end{array}$ & $\begin{array}{c}\text { Amylose } \\
\text { Content (\%) } \\
(\text { mean } \pm \text { SD ) }\end{array}$ & $\begin{array}{c}\text { Protein } \\
(\%) \\
(\text { mean } \pm \text { SD })\end{array}$ & $\begin{array}{l}\text { Gelatinization } \\
\text { Temperature }\end{array}$ \\
\hline BRRI dhan40 & $6.0 \pm 0.14^{\mathrm{d}}$ & $24.0 \pm 0.71^{\text {ef }}$ & $8.0 \pm 0.71^{\mathrm{d}}$ & Low \\
\hline BRRI dhan41 & $6.75 \pm 0.07^{\mathrm{e}}$ & $25.0 \pm 0.28^{\mathrm{fg}}$ & $6.4 \pm 0.0 .14^{\mathrm{a}}$ & Low \\
\hline BRRI dhan42 & $3.0 \pm 0.28^{\mathrm{ab}}$ & $25.0 \pm 0.14^{\mathrm{fg}}$ & $9.0 \pm 0.28^{\mathrm{ef}}$ & High-intermediate \\
\hline BRRI dhan43 & $3.0 \pm 0.78^{\mathrm{a}}$ & $23.0 \pm 0.57^{\mathrm{de}}$ & $8.8 \pm 0.14^{\mathrm{e}}$ & High-intermediate \\
\hline BRRI dhan47 & $7.0 \pm 0.14^{\mathrm{e}}$ & $27.0 \pm 0.28^{\mathrm{h}}$ & $6.2 \pm 0.28^{\mathrm{a}}$ & Low \\
\hline BRRI dhan51 & $4.9 \pm 0.14^{\mathrm{c}}$ & $25.0 \pm 0.42^{\mathrm{fg}}$ & $6.7 \pm 0.14^{\mathrm{ab}}$ & Intermediate \\
\hline BRRI dhan52 & $3.2 \pm 0.28^{\mathrm{b}}$ & $25.0 \pm 0.28^{\mathrm{fg}}$ & $7.0 \pm 0.14^{\mathrm{b}}$ & High-intermediate \\
\hline BRRI dhan53 & $3.0 \pm 0.14^{\mathrm{ab}}$ & $21.0 \pm 0.42^{\mathrm{bc}}$ & $7.2 \pm 0.14^{\mathrm{bc}}$ & High-intermediate \\
\hline BRRI dhan54 & $6.2 \pm 0.14^{\mathrm{d}}$ & $26.0 \pm 0.14^{\mathrm{gh}}$ & $6.4 \pm 0.14^{\mathrm{a}}$ & Low \\
\hline BRRI dhan55 & $3.0 \pm 0.14^{\mathrm{ab}}$ & $21.0 \pm 0.71^{\mathrm{bc}}$ & $7.0 \pm 0.14^{\mathrm{b}}$ & High-intermediate \\
\hline BRRI dhan56 & $7.0 \pm 0.07^{\mathrm{e}}$ & $25.0 \pm 0.07^{\mathrm{fg}}$ & $9.3 \pm 0.14^{\mathrm{f}}$ & Low \\
\hline BRRI dhan57 & $3.0 \pm 0.14^{\mathrm{ab}}$ & $24.0 \pm 0.00^{\mathrm{ef}}$ & $8.0 \pm 0.14^{\mathrm{d}}$ & High-intermediate \\
\hline BRRI dhan58 & $3.0 \pm 0.14^{\mathrm{ab}}$ & $26.0 \pm 0.28^{\mathrm{gh}}$ & $7.2 \pm 0.14^{\mathrm{bc}}$ & High-intermediate \\
\hline BRRI dhan59 & $3.0 \pm 0.14^{\mathrm{ab}}$ & $25.0 \pm 0.71^{\mathrm{fg}}$ & $7.6 \pm 0.14^{\mathrm{cd}}$ & High-intermediate \\
\hline BRRI dhan60 & $3.2 \pm 0.00^{\mathrm{b}}$ & $22.0 \pm 0.78^{\mathrm{cd}}$ & $7.1 \pm 0.14^{\mathrm{bc}}$ & High-intermediate \\
\hline BRRI dhan61 & $3.5 \pm 0.00^{\mathrm{b}}$ & $20.0 \pm 0.64^{b}$ & $7.2 \pm 0.07^{\mathrm{bc}}$ & High-intermediate \\
\hline BRRI dhan62 & $3.0 \pm 0.14^{\mathrm{ab}}$ & $19.0 \pm 0.78^{\mathrm{a}}$ & $7.9 \pm 0.07^{\mathrm{d}}$ & High-intermediate \\
\hline BRRI dhan63 & $3.0 \pm 0.14^{\mathrm{ab}}$ & $24.0 \pm 0.14^{\mathrm{ef}}$ & $8.1 \pm 0.00^{\mathrm{d}}$ & High-intermediate \\
\hline BRRI dhan64 & $3.0 \pm 0.00^{\mathrm{ab}}$ & $23.0 \pm 0.07^{\mathrm{de}}$ & $7.1 \pm 0.14^{\mathrm{bc}}$ & High-intermediate \\
\hline
\end{tabular}

Means with different superscripts in the same row differ significantly $(\mathrm{p}<0.05)$.

Alkali spreading value ranged from 3.0 to 7.0 of the tested varieties (Table 2). Alkali spreading value was found to be negatively correlated with the cooking time (Table 3) which indicates that cooking time is higher for those varieties which had low alkali spreading value i.e. high-intermediate gelatinization temperature (Graham, 2002). 
Table 3: Correlation co-efficient between Alkali spreading value and cooking time

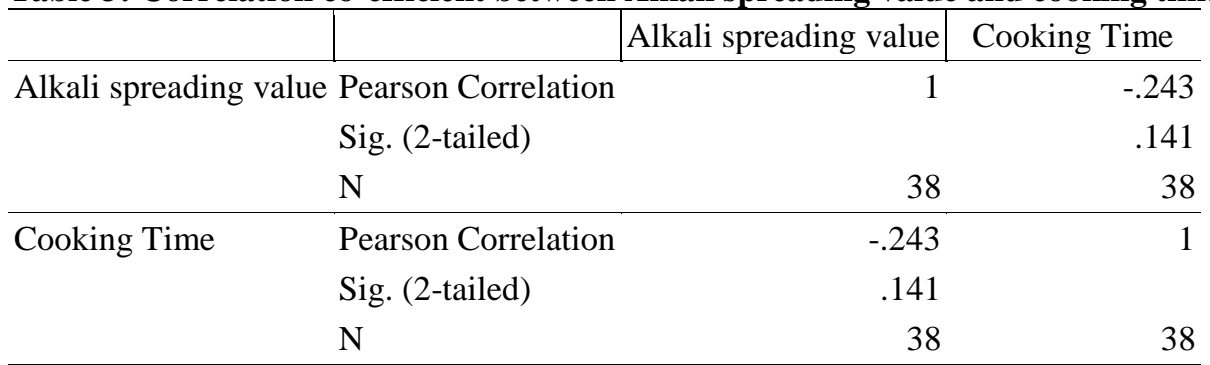

Cooking properties of nineteen rice varieties: Among the rice varieties BRRI dhan55 and BRRI dhan63 were long, slender and most of them were medium, medium in terms of size and shape. Cooking time varied from 13.0 minutes to 20.50 minutes among the tested fine rice varieties. Maximum cooking time was required in the variety of BRRI dhan40 and minimum in BRRI dhan54 (Table 4). Kernel elongation ratio of the rice varieties range from 1.1 to 1.5 (Table 4$)$. The kernel elongation ratio was greater than 1.1 in all the varieties except BRRI dhan62. The imbibition ratio was greater than 3.0 in all the varieties except BRRI dhan43 and BRRI dhan61 (Table 4).

Table 4. Cooking properties of nineteen non-abiotic and abiotic stress tolerant rice varieties

\begin{tabular}{lcccc}
\hline Variety/Line & $\begin{array}{c}\text { Size and } \\
\text { Shape } \\
\text { (milled rice) }\end{array}$ & $\begin{array}{c}\text { Cooking } \\
\text { Time (in min.) } \\
\text { (mean } \pm \text { SD })\end{array}$ & $\begin{array}{c}\text { Kernel Elongation } \\
\text { Ratio } \\
(\text { mean } \pm \text { SD })\end{array}$ & $\begin{array}{c}\text { Imbibition } \\
\text { Ratio } \\
(\text { mean } \pm \text { SD })\end{array}$ \\
\hline BRRI dhan40 & Medium, Medium & $20.5 \pm 0.00^{\mathrm{i}}$ & $1.4 \pm 0.14^{\mathrm{bc}}$ & $3.5 \pm 0.00^{\mathrm{b}}$ \\
BRRI dhan41 & Medium, Medium & $15.5 \pm 0.35^{\mathrm{cde}}$ & $1.4 \pm 0.00^{\mathrm{bc}}$ & $3.3 \pm 0.14^{\mathrm{b}}$ \\
BRRI dhan42 & Medium, Medium & $17.5 \pm 0.00^{\mathrm{gh}}$ & $1.3 \pm 0.14^{\mathrm{abc}}$ & $4.0 \pm 0.14 \mathrm{c}$ \\
BRRI dhan43 & Medium, Medium & $19.5 \pm 0.71^{\mathrm{i}}$ & $1.3 \pm 0.14^{\mathrm{abc}}$ & $3.0 \pm 0.14^{\mathrm{a}}$ \\
BRRI dhan47 & Medium, Bold & $17.00 \pm 0.71^{\mathrm{fgh}}$ & $1.5 \pm 0.07^{\mathrm{c}}$ & $4.3 \pm 0.00^{\mathrm{d}}$ \\
BRRI dhan51 & Short, Medium & $15.5 \pm 0.00^{\mathrm{cde}}$ & $1.5 \pm 0.07^{\mathrm{c}}$ & $3.5 \pm 0.07^{\mathrm{b}}$ \\
BRRI dhan52 & Medium, Medium & $16.0 \pm 0.71^{\mathrm{def}}$ & $1.4 \pm 0.00^{\mathrm{bc}}$ & $4.3 \pm 0.14^{\mathrm{d}}$ \\
BRRI dhan53 & Medium, Medium & $18.0 \pm 0.00^{\mathrm{h}}$ & $1.2 \pm 0.07^{\mathrm{ab}}$ & $4.3 \pm 0.07^{\mathrm{d}}$ \\
BRRI dhan54 & Medium, Medium & $13.0 \pm 0.00^{\mathrm{a}}$ & $1.4 \pm 0.07^{\mathrm{bc}}$ & $3.5 \pm 0.00 \mathrm{~b}$ \\
BRRI dhan55 & Long, Slender & $15.0 \pm 0.71^{\mathrm{bcd}}$ & $1.3 \pm 0.07^{\mathrm{abc}}$ & $4.7 \pm 0.07^{\mathrm{e}}$ \\
BRRI dhan56 & Medium, Medium & $14.5 \pm 0.00^{\mathrm{bc}}$ & $1.5 \pm 0.07^{\mathrm{c}}$ & $3.5 \pm 0.14^{\mathrm{b}}$ \\
BRRI dhan57 & Medium, Slender & $15.5 \pm 0.71^{\mathrm{cde}}$ & $1.2 \pm 0.14^{\mathrm{ab}}$ & $4.3 \pm 0.00^{\mathrm{d}}$ \\
BRRI dhan58 & Medium, Medium & $16.5 \pm 0.71^{\mathrm{efg}}$ & $1.3 \pm 0.00^{\mathrm{abc}}$ & $3.5 \pm 0.07^{\mathrm{b}}$ \\
BRRI dhan59 & Medium, Medium & $17.0 \pm 0.71^{\mathrm{fgh}}$ & $1.3 \pm 0.07^{\mathrm{abc}}$ & $3.5 \pm 0.07^{\mathrm{b}}$ \\
BRRI dhan60 & Medium, Medium & $17.5 \pm 0.71^{\mathrm{gh}}$ & $1.4 \pm 0.07^{\mathrm{bc}}$ & $3.5 \pm 0.07^{\mathrm{b}}$ \\
BRRI dhan61 & Medium, Medium & $16.0 \pm 0.71^{\mathrm{def}}$ & $1.3 \pm 0.07^{\mathrm{abc}}$ & $3.0 \pm 0.14^{\mathrm{a}}$ \\
BRRI dhan62 & Medium, Medium & $16.5 \pm 0.00^{\mathrm{efg}}$ & $1.1 \pm 0.07^{\mathrm{a}}$ & $3.3 \pm 0.07^{\mathrm{b}}$ \\
BRRI dhan63 & Long, Slender & $14.0 \pm 0.00^{\mathrm{ab}}$ & $1.5 \pm 0.07^{\mathrm{c}}$ & $3.5 \pm 0.07^{\mathrm{b}}$ \\
BRRI dhan64 & Medium, Bold & $20.0 \pm 0.00^{\mathrm{i}}$ & $1.3 \pm 0.07^{\mathrm{abc}}$ & $3.3 \pm 0.14^{\mathrm{b}}$ \\
\hline
\end{tabular}

Means with different superscripts in the same row differ significantly $(\mathrm{p}<0.05)$. 
Kernel elongation ratio was significantly and positively correlated with the amylose content (Table 5) which indicates that the elongation was high for those varities which had high amylose content. It is an important parameter for cooked rice. If rice kernel elongates more lengthwise it gives a finer appearance and if expands girth wise, it gives a coarse look (Dipti et al., 2002).

Table 5. Correlation co efficient between Elongation ratio and amylose content

\begin{tabular}{l|rrr}
\hline & & Elongation ratio & Amylose content \\
\hline Elongation ratio & Pearson Correlation & 1 & $.550^{* *}$ \\
& Sig. (2-tailed) & & .000 \\
& $\mathrm{~N}$ & 38 & 38 \\
\hline Amylose content & Pearson Correlation & $.550^{* *}$ & 1 \\
& Sig. (2-tailed) & .000 & 38 \\
& $\mathrm{~N}$ & 38 & 38 \\
\hline
\end{tabular}

**. Correlation is significant at the 0.01 level (2-tailed).

The water uptake during cooking was significantly and negatively correlate (Table 6) with optimum cooking time. However, higher the imbibition ratio of rice, lower will be the energy content per unit volume or weight of cooked rice as they will have more water and less solid materials (Anon., 1997).

Table 6. Correlation coefficient between cooking time and imbibition ratio

\begin{tabular}{l|lrr}
\hline & & Cooking Time & Imbibition ratio \\
\hline Cooking Time & Pearson Correlation & 1 & -.171 \\
& Sig. (2-tailed) & & .306 \\
& $\mathrm{~N}$ & 38 & 38 \\
\hline Imbibition ratio & Pearson Correlation & -.171 & 1 \\
& Sig. (2-tailed) & .306 & \\
& $\mathrm{~N}$ & 38 & 38 \\
\hline
\end{tabular}

\section{Conclusion}

Significant differences of chemical and cooking properties of the non-abiotic and abiotic stress tolerant rice varieties with the other high yielding rice varieties was not found.. This is because the abiotic stress tolerant varieties (salinity, drought and submergence tolerant) are grown in normal condition. Among the varieties BRRI dhan56 showed highest amount of protein, where highest amount of amylose content was found in BRRI dhan47. Further study is necessary growing the abiotic stress tolerant varieties in stress condition.

\section{References}

Anonymous. 1999. Annual report for 1999. Bangladesh Rice Research Inst. Gazipur. P. 29.

Anonymous. 2014a. Growing rice under stress environment. Available at http://www.thedailystar.net/growing-rice-under-stress-environment-15447. 
Anonymous. 2014b. BRRI at a glance. Available at http://old bans.doc.gov.bd./sub4/204brri/files/

Asghar, S., F. M. Anjum., R. M. Amir and M. A. Khan, 2012. Cooking and eating characteristics or rice (Oryza sativa L.). Pakistan Journal of Food Sciences, 22(3): 128-132.

Azeez, M. A. and M. Shafi. 1966. Quality in rice. Dept. Agr. (W. Pakistan) Tech. Bull. No. 13, P. 23.

Cameron, D. K., Y. J. Wang and K. A. Moldenhauer. 2008. Comparision of Physical and Chemical Properties of Medium Grain Rice Cultivars Grown in California and Arkansas. Journal of Food Science, Vol. 73, No. 2, Pp. C72-C78.

Dipti, S. S., S.T. Hossain, M. N. Bari and K. A. Kabir, 2002. Physicochemical and Cooking Properties of Some Fine Rice Varieties. Pakistan Journal of Nutrition 1 (4): 188-190.

Graham, R. 2002. A Proposal for IRRI to Establish a Grain Quality and Nutrition Research Center.

Juliano, B. O. 1971. A simplified assay for milled rice amylose. Cereal. Sci. Today. 16: 334-338, 340, 360.

Juliano, B. O. 1979. The chemical basis of rice grain quality In: Proc chemical aspect of rice grain quality. IRRI, Philippines. Pp. 69-90.

Juliano, B. O. 1985. Polysacharides, Protein and lipids of rice. In: Rice chemistry and Technology (B. O. Juliono ed.) 2nd edition. Am. Assoc. Cereal Chem. St. Paul. Pp. 59-179.

Little R. R., G.B. Hilder and E.H. Dawson. 1958. Differential effect of dilute alkali on 25 varieties of milled white rice. Cereal Chem. 35:111-126.

SAS. 1985. SAS Users guiode: statistics, version $5^{\text {th }}$ ed. SAS institute. Inc. cary, NC. 
